\title{
Influence of Silvicultural Techniques on the Occurrence of Compression Wood and Consequences on Wood Quality
}

\author{
Vinícius Rosa Schweitzer ${ }^{1}$, Jorge Luis Monteiro de Matos ${ }^{2}$, Martha Andreia Brand ${ }^{2}$, José Guilherme Prata ${ }^{1}$ \\ ${ }^{1}$ Federal University of Paraná, Forestry Department, Forest Engineering Course, Curitiba - PR. Brazil \\ ${ }^{2}$ Federal University of Paraná, Forestry Department, Forest Engineering Course, Curitiba - PR. Brazil \\ ${ }^{2}$ Federal University of Paraná, Forestry Department, Forest Engineering Course, Lages - SC. Brazil \\ ${ }^{1}$ Membership: Federal University of Paraná, Forestry Department, Forest Engineering Course, Curitiba - PR. Brazil
}

Correspondence Author: Vinícius Rosa Schweitzer, Federal University of Paraná, Forestry Department, Forest Engineering Course, Curitiba - PR. Brazil E-mail: florestalvinicius@gmail.com

Received date: 15 August 2019, Accepted date: 30 September 2019, Online date: 28 October 2019

Copyright: $\odot 2019$ Vinícius Rosa Schweitzer et al, This is an open-access article distributed under the terms of the Creative Commons Attribution License, which permits unrestricted use, distribution, and reproduction in any medium, provided the original author and source are credited.

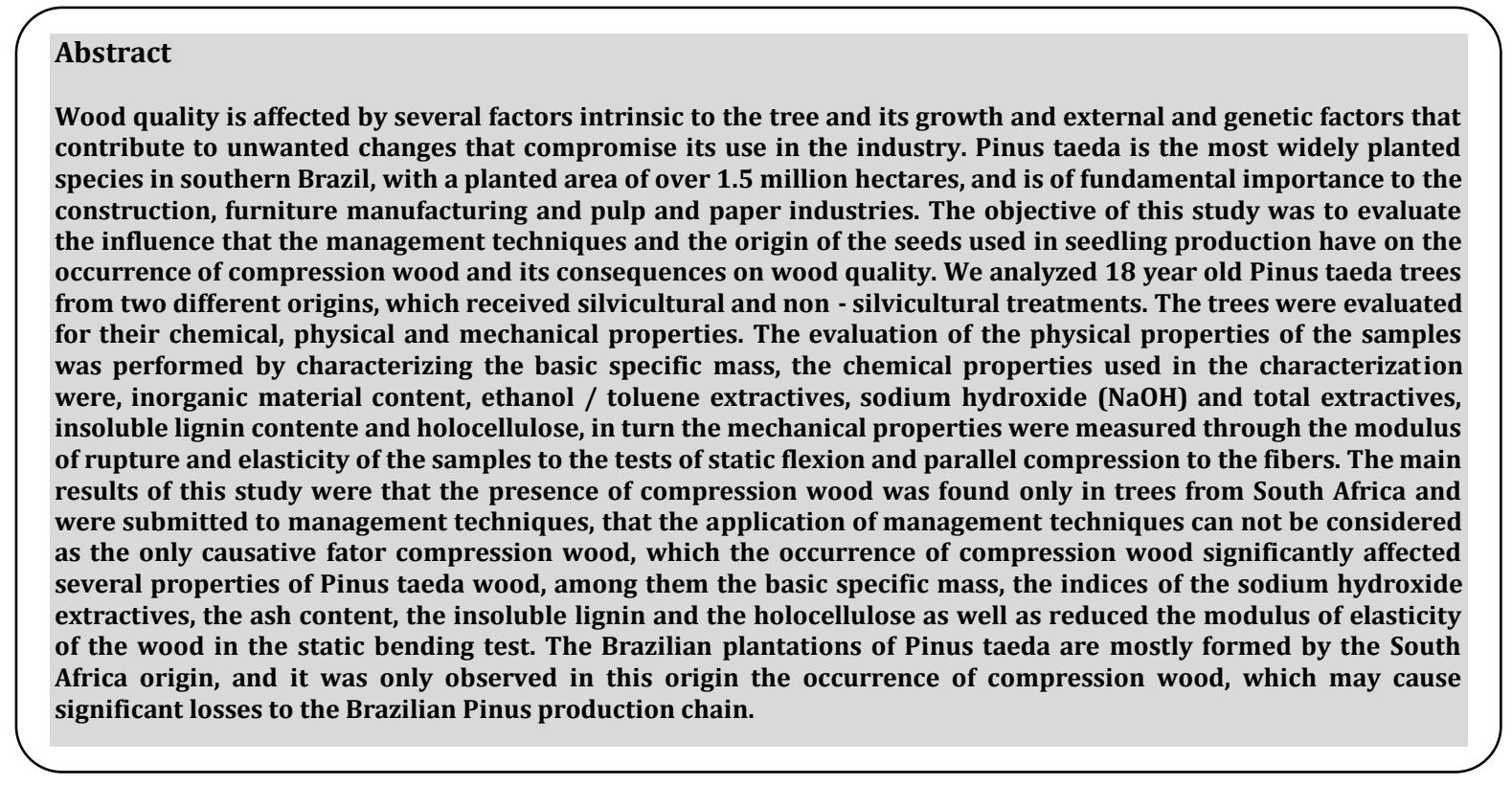

Keywords: Pinus taeda; properties; wood quality; abnormal compression wood of compression

\section{INTRODUCTION}

As a tree grows, it increases the exposure of the trunk to mechanical stresses. The most common efforts are those caused by the tree's own growth and the incidence of natural factors. In the case of external stresses, the trees respond to these mechanical loads by changing their composition, modifying their physical and chemical structure to compensate for the unfavourable situation (KIM et al., 2016). To this wood, formed with distinct characteristics of the wood usually produced by the tree, is given the name of wood of reaction.

Compression wood, defined as the reaction wood that occurs in Gymnosperms, is one of the main defects that affect the quality of the wood, due to the uneven growth of the trees. At research on this topic, today is rare, especially in the field of understanding how compression wood is formed.

Tomazello and Silva (1987) reported as the main known causes of compression wood formation: (i) the growth characteristics of the species, related to their genotype, such as tortuosity of the trunk, formation of the crown, branches, among others; (ii) training techniques and forest management, such as seedling quality, spacing, thinning and deforestation; (iii) the incidence of external agents, mainly winds, acting on one side of the trunk or tree; (iv) stimulation of exchange rate activity by growth hormones, such as auxin, on the trunk face opposite the slope. 
Citation: Vinícius Rosa Schweitzer, et al., Influence of Silvicultural Techniques on the Occurrence of Compression Wood and Consequences on Wood Quality. Australian Journal of Basic and Applied Sciences, 13(10): 48-54. DOI: 10.22587/ajbas.2019.13.10.7

In the 1980s, Timell (1986) reported that the alterations presented by compression wood occur in anatomical, chemical and physical properties. Changes in these properties affect the quality of the wood, influencing the final use, whether in laminated form, unfolded or as a source of cellulose and paper.

Within the group of gimonosperms, the economic importance that the genus Pinus has for the southern region of the country is expressive, and more than $60 \%$ of the planted forest areas in this region of Brazil are composed of species of this genus, being Pinus taeda the most relevant (IBA, 2017). According to the same author, Pinus taeda forests cover an additional 1.5 million hectares in the states of Santa Catarina, Paraná and Rio Grande do Sul, is fundamental for the production chain of civil construction, lumber and the production of pulp and paper.

Although the production of Pinus taeda wood has been going on for several years without major problems, in recent years companies have reported various abnormalities in wood quality. These range from changes in the colouring of the parts to the locking of some logs in the de-bending equipment, in addition to high defect rates in the drying process. These occurrences coincide with the presence of compression wood in the trees and parts.

The most relevant fact is that the trees that present the wood of compression are not in conditions related to the known causes, that favors the formation of this wood. Considering previous researches and company reports, it is necessary to study and evaluate the aspects that can lead to the formation of compression wood in the region of study.

The objective of this work was to analyze the influence of management techniques and origin on the occurrence of compression wood in Pinus taeda trees and their consequences on wood quality.

\section{MATERIALS AND METHODS}

Twenty individuals of Pinus taeda, 18 years old, were selected in two plantations in the state of Santa Catarina, located in the municipalities of Ponte Alta do Norte and Santa Cecília, in the southern latitudes of $26^{\circ}$ and $27^{\circ}$ respectively, and west longitude of $50^{\circ}$. The selection of these two areas was made based on the report of occurrence of the wood of compression by forest companies of the region. The stands of both studied areas had the same number of trees per hectare and even line spacing, 2,50 $\mathrm{x}$ $2,50 \mathrm{~m}$. Another criterion for the selection of areas was based on the similarity of environmental and climatic conditions.

In the sampled trees, the total height silvicultural and chest height circumference (CAP) data, presented in table 1 , were obtained. Six discs were extracted at six heights along the shaft, 0\%, CAP, 25\%, 50\%, 75\% and 100\% of the commercial height and also a board that was obtained between the disks of the CAP and the height of $25 \%$.

Table 1: Average cap and height values of sampled trees.

\begin{tabular}{|c|c|c|}
\hline Treatment & CAP $(\mathbf{c m})$ & Height $(\mathbf{m})$ \\
\hline $\mathrm{T} 1$ & $83,7 \mathrm{a}(9,70)$ & $14,3 \mathrm{a}(5,59)$ \\
\hline $\mathrm{T} 2$ & $103,56 \mathrm{~b}(6,37)$ & $13,4 \mathrm{a}(6,08)$ \\
\hline $\mathrm{T} 3$ & $90,54 \mathrm{ab}(2,69)$ & $14,24 \mathrm{a}(3,96)$ \\
\hline $\mathrm{T} 4$ & $92 \mathrm{ab}(11,67)$ & $13,62 \mathrm{a}(8,05)$ \\
\hline
\end{tabular}

The mean values followed by the same letter and in the same column do not differ statistically. Values in parentheses refer to the coefficient of variation between samples.

A completely randomized experimental design consisted of four treatments, with 5 individuals (trees) collected per treatment. The treatments are described in Table 2.

Table 2: Description of the treatments collected

\begin{tabular}{|c|c|c|c|c|}
\hline \multirow{2}{*}{ Description } & \multicolumn{4}{|c|}{ Treatments } \\
\cline { 2 - 5 } & T1 & T2 & T3 & T4 \\
\hline Provenance & South Africa & South Africa & South Africa & Geórgia \\
\hline Silvicultural treatments & pruned & pruned & not pruned & pruned \\
\hline Management & thinned & thinned & untrimmed & thinned \\
\hline Compression wood & Ausente & Presente & Ausente & Ausente \\
\hline
\end{tabular}

Treatment 1 (T1) consisted of trees that did not have external and internal characteristics that indicated the presence of compressive wood, such as eccentricity of the crown, asymmetric shaft, sharp conicity and dark coloration of wood. This treatment had, therefore, trees with normal wood, without the presence of wood of compression.

Treatment 2 (T2) had the same origin of the seeds and the same silvicultural treatments and management of the treatment 1. However, both the external characteristics of the tree and the coloring of the wood after the clearing of the individuals indicated the presence of compression wood.

Treatment 3 (T3) had the same origin as the previous treatments, but the trees were collected in a plantation where the silvicultural and management treatments used in the previous treatments were not applied.

Finally, treatment 4 (T4) had the same management and silvicultural treatments as treatments 1 and 2 , but with a different origin from the previous ones.

The selection of provenances studied in this work was carried out according to the improvement program applied to the stands of the region, which identified that for the production of high quality logs in the region, seeds from South Africa and 
Citation: Vinícius Rosa Schweitzer, et al., Influence of Silvicultural Techniques on the Occurrence of Compression Wood and Consequences on Wood Quality. Australian Journal of Basic and Applied Sciences, 13(10): 48-54. DOI: 10.22587/ajbas.2019.13.10.7

Georgia are the most indicated, The treatments T1, T2 and T3 were then produced with seeds from South Africa and T4 with seeds from Gerogy (USA).

For the evaluation of the management techniques, T1, T2 and T4 samples were submitted to pruning and thinning, but the T3 sample did not undergo any of the techniques mentioned above.

Table 3 presents the tests carried out to determine if the seed origin or the management techniques influence the occurrence of the wood compression and what the consequences on the quality of the wood.

\section{Statistical analysis}

The data resulting from these evaluations were grouped by the mean values obtained in the tests described above. The data resulting from these evaluations were grouped by the mean values obtained. Statistical analysis was performed using Statpraphics ${ }^{\circledR}$ software, version 16.1.11, by the ANOVA test with the Tukey test with $95 \%$ confidence.

Table 3: Response variables collected to evaluate the effects of the presence of compression wood on Pinus taeda wood.

\begin{tabular}{|c|c|c|}
\hline \multicolumn{2}{|c|}{ Test } & Standard \\
\hline Physical Analysis & Basic specifc mass & COPANT 461 - Determinación Del peso especifico aparente \\
\hline \multirow{2}{*}{ Mechanical Analysis } & Compression parallel to fibers & COPANT 464 - Metodo de determinación de la compresión parallel al grano \\
\hline \multirow{4}{*}{ Chemical Analysis } & Static bending & COPANT 555 - Metodo de ensayo de flexion estatica \\
\cline { 2 - 3 } & Insoluble lignin & NBR 7989 - Determinação da lignina insolúvel em ácido. \\
\cline { 2 - 3 } & Extratives in NaOH & NBR 7990 - Determinação do material solúvel em hidróxido de sódio a 1\% \\
\cline { 2 - 3 } & Ash Content & NBR 13999 - Determinação do Material Inorgânico. \\
\cline { 2 - 3 } & Extracts in Ethanol-Toluene & NBR 14853 - Determinação do material solúvel em etanol:tolueno e em \\
diclorometano.
\end{tabular}

The plank collected in the sampled trees was used to obtain the specimens used to determine the physical and mechanical properties of all treatments.

The determination of the chemical properties of treatments 1 and 2 were performed from the discs collected in the DAP of the trees of these treatments. The objective of establishing the chemical properties of these treatments alone was to confirm if the visual differences used in the selection of these individuals would confirm the presence of the compression wood in the treatment 2.

\section{RESULTS}

The mean values of the chemical analyzes are presented in Table 4.

Table 4: Structural chemical composition of Pinus taeda wood with and without the presence of compressive wood

\begin{tabular}{|c|c|c|}
\hline Treatment & T1 & T2 \\
\hline Mat. inorganic (\%) & $0,26 \mathrm{a}(10,02)$ & $0,33 \mathrm{~b}(6,20)$ \\
\hline NaOH $^{1}(\%)$ & $3,71 \mathrm{a}(10,84)$ & $11,34 \mathrm{~b}(7,16)$ \\
\hline Ethanol-toluene (\%) & $2,31 \mathrm{a}(11,08)$ & $2,33 \mathrm{a}(12,91)$ \\
\hline total extractives (\%) & $3,70 \mathrm{a}(0,89)$ & $3,73 \mathrm{a}(3,21)$ \\
\hline lignin (\%) & $26,94 \mathrm{a}(0,91)$ & $32,00 \mathrm{~b}(0,86)$ \\
\hline Holocellulose $^{2}(\%)$ & $63,08 \mathrm{a}(7,75)$ & $50,26 \mathrm{~b}(8,44)$ \\
\hline
\end{tabular}

Averages followed by the same letter on the same line are statistically the same. ${ }^{1}$ Solubility in $1 \%$ sodium hydroxide. ${ }^{2}$ Holocellulose determined by difference. The values in parentheses refer to the value of the coefficient of variation $(\%)$.

Regarding the inorganic materials (ash), it can be verified that the average values present statistical differences between the treatments, being the value of T2 27\% higher than T1. The value obtained for T1 is similar to that found by Trianoski (2012) and Andrade (2006), who found average values of $0,28 \%$ and $0,26 \%$, respectively.

Regarding the content of soluble components in sodium hydroxide, it can be stated that the sample T2 presented an average value three times higher than that of $\mathrm{T} 1$.

According the ethanol-toluene and total extractives contents, both treatments had average values close to each other, and no statistical difference was observed between them.

The difference in lignin content of T2 is $18 \%$ greater than that of $\mathrm{T} 1$, in holocellulose content this is opposite behavior, as $\mathrm{T} 2$ has $20 \%$ less compared to T1.

The mean values of specific mass for the treatments and for the six collection heights are presented in Table 5 .

Table 5: Average specific mass values according to the collection height in the analyzed tranches

\begin{tabular}{|c|c|c|c|c|}
\hline \multirow{2}{*}{ Position } & \multicolumn{4}{|c|}{ Basic specific mass $\left(\mathbf{g} / \mathbf{c m}^{3}\right)$} \\
\cline { 2 - 5 } & T1 & T2 & T3 & T4 \\
\hline Top & $0,333 \mathrm{a}(6,95)$ & $0,350 \mathrm{a}(17,90)$ & $0,327 \mathrm{a}(7,87)$ & $0,323 \mathrm{a}(3,62)$ \\
\hline $75 \%$ & $0,316 \mathrm{ab}(3,82)$ & $0,362 \mathrm{a}(12,50)$ & $0,318 \mathrm{ab}(7,61)$ & $0,308 \mathrm{~b}(4,78)$ \\
\hline $50 \%$ & $0,336 \mathrm{ab}(7,10)$ & $0,374 \mathrm{a}(10,40)$ & $0,321 \mathrm{~b}(3,71)$ & $0,312 \mathrm{~b}(5,39)$ \\
\hline
\end{tabular}


Citation: Vinícius Rosa Schweitzer, et al., Influence of Silvicultural Techniques on the Occurrence of Compression Wood and Consequences on Wood Quality. Australian Journal of Basic and Applied Sciences, 13(10): 48-54. DOI: 10.22587/ajbas.2019.13.10.7

\begin{tabular}{|c|c|c|c|c|}
\hline $25 \%$ & $0,368 \mathrm{~b}(9,61)$ & $0,425 \mathrm{a}(7,05)$ & $0,346 \mathrm{~b}(8,12)$ & $0,335 \mathrm{~b}(4,91)$ \\
\hline $\mathrm{DAP}$ & $0,396 \mathrm{ab}(4,70)$ & $0,436 \mathrm{a}(10,23)$ & $0,381 \mathrm{~b}(5,34)$ & $0,374 \mathrm{~b}(5,13)$ \\
\hline Base & $0,417 \mathrm{a}(9,03)$ & $0,440 \mathrm{a}(9,96)$ & $0,392 \mathrm{a}(5,74)$ & $0,381 \mathrm{a}(7,15)$ \\
\hline Average & $0,361 \mathrm{~B}(12,16)$ & $0,398 \mathrm{~A}(13,96)$ & $0,348 \mathrm{~B}(10,39)$ & $0,339 \mathrm{~B}(9,93)$ \\
\hline
\end{tabular}

The mean values obtained followed by the same letter and on the same line do not differ statistically from each other by the Tukey test with $95 \%$ confidence. Values in parentheses refer to coefficient of variation between samples $(\%)$.

It is verified that in the base and at the top of the trees, the mean values obtained do not present significant statistical differences. However, for the intermediate heights (DAP, 25\%, 50\% and 75\%) T2 treatment had the highest mean values and differed statistically from the others. The same behavior was observed when analyzing the general mean values. T2 presented higher value and differed statistically among the others. It can be stated that the average specific mass of the treatments T1, T3 and $\mathrm{T} 4$ are statistically equal, and it can be inferred that the management techniques and the provenance do not influence this variable for the mean values of specific mass.

The average results obtained for the modulus of rupture and for the modulus of elasticity from the static bending test are shown in Table 6.

Table 6: Average results of resistance to static and dynamic flexion by treatment

\begin{tabular}{|c|c|c|c|}
\hline Treatment & MOR (MPa) & MOEdin. (MPa) & MOE (MPa) \\
\hline T1 & $57 \mathrm{a}(21,06)$ & $6633,66 \mathrm{a}(37,45)$ & $5504,38 \mathrm{a}(39,99)$ \\
\hline T2 & $57 \mathrm{a}(23,10)$ & $5170,1 \mathrm{~b}(28,96)$ & $4279,14 \mathrm{~b}(27,30)$ \\
\hline T3 & $49 \mathrm{~b}(25,92)$ & $5563,20 \mathrm{~b}(26,51)$ & $4593,10 \mathrm{ab}(29,95)$ \\
\hline T4 & $50 \mathrm{~b}(25,56)$ & $5405,08 \mathrm{~b}(31,67)$ & $4732,72 \mathrm{a}(32,69)$ \\
\hline
\end{tabular}

MOR: modulus of rupture; MOEdin: Modulus of Dynamic Elasticity; MOE: modulus of elasticity. Means followed by the same letter in the same column are statistically the same by the Tukey test at $95 \%$ probability. Values in parentheses refer to the coefficient of variation between samples.

According to the results described, it can be verified that the highest mean value for the modulus of rupture was obtained for $\mathrm{T} 1$ and T2, where these similar treatments were different from the others. The elasticity modulus showed that T1 had the highest mean value among treatments, differing statistically from T2, T3 and T4.

For the MOR only the pruning and the non-pruning and roughing affected the quality of the wood, but the presence of the wood of compression does not seem to have had influence in the observed variations.

For the MOEdin., The origin of South Africa with normal wood had the best performance, and the presence of the compression wood affected the quality of the wood.

For the MOE, the presence of the compressive wood reduced the observed values, making this treatment similar in performance to the material that was not subjected to pruning and slabs.

The results obtained from the parallel compression test in the samples can be visualized in table 7 .

Table 7: Average values of resistance to compression parallel the fibers obtained in the different treatments

\begin{tabular}{|c|c|c|}
\hline Treatment & MOR (MPa) & MOE (MPa) \\
\hline T1 & $29 \mathrm{a}(10,21)$ & $7618,14 \mathrm{a}(13,45)$ \\
\hline T2 & $26 \mathrm{ab}(15,08)$ & $6875,73 \mathrm{ab}(10,26)$ \\
\hline T3 & $24 \mathrm{ab}(12,10)$ & $6527,73 \mathrm{a}(15,18)$ \\
\hline T4 & $24 \mathrm{~b}(13,61)$ & $6297,74 \mathrm{~b}(12,12)$ \\
\hline
\end{tabular}

MOR: modulus of rupture; MOE: modulus of elasticity.

Means followed by the same letter in the same column are statistically the same by the Tukey test at $95 \%$ probability. Values in parentheses refer to the coefficient of variation between samples.

The highest average value for the modulus of rupture in parallel compression was obtained for T1, and the presence of the compressive wood and the lack of pruning and thinning did not influence the quality of the wood, but the origin did. For T2, although it has the largest specific mass among the treatments, this did not represent significant gains in the resistance, due to the fact that it is a compression wood. For the MOE, the provenance South Africa with normal timber performed best. Since the presence of wood compression and non - pruning and management reduced the value of resistance, making these treatments similar to the individuals from the "Georgia" origin.

Considering the results of resistance to parallel compression, The highest average value was obtained for T1, and the presence of compression wood and lack of pruning and thinning did not influence the quality of the wood, but the origin did. For T2, although it has the highest specific mass between treatments, this did not represent significant gains in strength due to the fact that it is a compression wood.

\section{DISCUSSIONS}

In organic terms, wood is a material formed by a chemical complex of cellulose, hemicellulose, lignin and extractives, which are related to its properties. The distribution of these components is very varied, their concentration changes according to the 
Citation: Vinícius Rosa Schweitzer, et al., Influence of Silvicultural Techniques on the Occurrence of Compression Wood and Consequences on Wood Quality. Australian Journal of Basic and Applied Sciences, 13(10): 48-54. DOI: 10.22587/ajbas.2019.13.10.7

species, silvicultural treatments and growth conditions (SEVERO; CALANSEGO, SANSÍGOLO, 2006), due to this, Klock (2005) states that it is of fundamental importance the understanding of these chemical componentes.

According to Fengel and Wegener (1989), the minerals that form the ashes are incorporated into the trees throughout the production period. Application of the latest components in applications is application limit and shortens the life of cutting machines. Despite the statistical difference, the values are considered according to the researched literature.

Sodium hydroxide-soluble components indicate the degree of decomposition that wood has undergone by agents such as fungi, light, heat and oxidation. Considering the results presented in the literature by Mendes (2001) and Trianoski (2012) of $12,98 \%$ and $9,31 \%$, these values are similar to the average value obtained for T2. For this property, the values obtained for the compression wood were closer to those obtained for the wood considered in the study as normal.

It is known that extractives are components that are not part of the chemical structure of the cell wall and are responsible for characteristics such as color, smell, natural resistance to rot, taste and even abrasive properties, possessing a great variety of possible components. These minor components have a content of 3\% to 5\% in conifers (Klock, 2005). Based on the above, it can be stated that the treatments do not have significant differences in these components, and that the visual changes caused in $\mathrm{T} 2$ are due to changes in the cell wall and / or the middle lamella.

Regarding the major components, holocellulose and lignin, it can be observed that these variables are the ones that present the most significant differences between the treatments. The term holocellulose is applied to be called cellulose, together with the other polysaccharides of wood. The determination of this variable is done by totally removing the lignin and extractives from the sample. Lignin corresponds to the third most abundant component of wood; the amorphous substance located on the middle lamella, as well as on the secondary wall, with the function of stiffening the cell walls (FENGEL; WEGENER, 1989) (KLOCK et al., 2005). Considering the results presented in the literature, Mendes (2001) obtained lignin contents of 27,23\%, Bortoletto Junior (1999) found lignin values of $28,76 \%$ and holocellulose values between 70,70\% and 72,73\%. On the other hand, Trianoski (2012), conducting a study in conditions similar to this one, obtained lignin content of $29,34 \%$ and holocellulose of $63,03 \%$. The results between these researches can be considered compatible with each other, although these values are similar among the values obtained in this work, it is of fundamental importance to point out the difference between the treatments.

The obtained values confirm that the wood of $\mathrm{T} 2$ is in fact, wood of compression, this is also evidenced by data of literature. Timell (1986) observed similar behavior in trees of the same genus, where the cellulose content was $20 \%$ lower in the compression wood when compared to "normal" wood. The lignin content was $38 \%$ higher, while the extractive values had close values, 2,75\% for the compression wood and 2,45\% for the normal wood. Kwon et al. (2001) and Yamashita et al. (2009) stated that the lignin content is significantly higher than in normal wood and that the visual change observed in the compression wood can be attributed in part to this increase in the amount of lignin.

Among the parameters used to determine wood quality, specific mass is highly relevant as it is closely linked to economic and technological characteristics. Castelo (2007) mentioned dimensional change, mechanical strength of parts, production and quality of pulp and coal, as well as operating costs related to the transportation and storage of Wood as some points where specific mass directly affects the process and to products. Therefore, it is considered by industries as one of the most important properties, as it is easy to measure and is related to various process and final product characteristics. Thus, it can be stated that the average specific mass of treatments T1, T3 and T4 are statistically equal, and it can be inferred that management techniques and origin do not influence this variable for the average values of specific mass.

The results obtained for the specific mass of the different treatments presented values below those described by Trianoski et al. (2013) in a study of Pinus taeda and similar age studied in this study, where the observed value was $0,467 \mathrm{~g} / \mathrm{cm}^{3}$. Santini et al. (2000), Melchiorretto and Eleoterio (2003) measured average values of specific mass with a great similarity with this work, with a value of $0,410 \mathrm{~g} / \mathrm{cm}^{3}$ and $0,370 \mathrm{~g} / \mathrm{cm}^{3}$, respectively. Due to the constitution of each tree, species and individuals have their own specific masses, this parameter being the result of the physiological process of plants and the complex combination of chemical elements (CASTELO, 2007). This explains why T2 has higher average values of specific mass. The chemical constitution of this treatment is different from the others, the higher concentration of lignin and less evidence of holocellulose, because this treatment has a higher specific mass than the others.

Regarding the static flexion test, compared to the values described by other researches with the same species, it is observed that Santini et al. (2000) evaluating 13-year-old trees found values of 54,5 MPa and 5840,90 MPa for MOR and MOE, respectively, values below those described for T1 and above the others. The same goes for the values described by Melchiorretto and Eleoterio (2003) who obtained $49 \mathrm{MPa}$ for MOR and 6329,60 for MOE in a study with 25-year-olds. Trianoski et al. (2014) in trees of the same age determined for MOR, $64 \mathrm{MPa}$ and MOE $8234 \mathrm{MPa}$. According to Ferrante (2002), this variable is an intrinsic property of the material and depends on the stiffness of atomic bonds, as well as the density of bonds, in practical terms, the modulus of elasticity demonstrates the stiffness of wood. Matos (1997) stated that some materials have considerable reserves between the resistance between the elastic limit and the maximum resistance, if this occurred with $\mathrm{T} 2$.

In the parallel fiber compression test the values found in the literature were similar to those obtained in this paper, for example, Santini et al. (2000) obtained for the rupture modulus 28,54 MPa and elasticity modulus of 8591,20 MPa for 13-year-old plantings; Trianoski et al. (2014) established a rupture modulus of $37 \mathrm{MPa}$ and a modulus of elasticity of 12,432 MPa. These results are superior to those described in this paper. Brand et al. (2004) and Figueroa and Moraes (2016), defined rupture modulus of 26,7 MPa and $24 \mathrm{MPa}$ respectively.

\section{CONCLUSIONS}

- The management techniques and provenances studied have an impact on wood quality and the relationship with the occurrence of compression wood. 
Citation: Vinícius Rosa Schweitzer, et al., Influence of Silvicultural Techniques on the Occurrence of Compression Wood and Consequences on Wood Quality. Australian Journal of Basic and Applied Sciences, 13(10): 48-54. DOI: 10.22587/ajbas.2019.13.10.7

- Compression wood was observed only in South African trees.

- The occurrence of compression wood increased the specific mass indexes, extractives of HaOH, lignin and holocellulose.

- The mechanical properties of Pinus taeda wood were negatively affected in the static bending test and positively in the parallel fiber compression test.

- The occurrence of compression wood directly affected the quality of Pinus taeda wood.

\section{LIMITATIONS AND RECOMMENDATIONS}

- Evaluate the technological and financial impacts of this problem in the productive chain.

- Determine the occurrence rate of compression wood in plantations.

- Intensify research on compression wood, as there are few Brazilian references on the subject.

\section{ACKNOWLEDGMENTS}

The authors acknowledge Federal University of Paraná (UFPR) and the Santa Cataria State University (UDESC), Forestry Engineering course, for the partnership established to carry out this research.

\section{ENDNOTES}

'All the authors contributed equally to this Work'.

\section{REFERENCES}

ANDRADE, A.S de. Qualidade da madeira, celulose e papel em Pinus taeda L.: influência da idade e da classe de produtividade. 94 f. Dissertação (Mestrado em Engenharia Florestal) - Setor de Ciências Agrárias, Universidade Federal do Paraná, Curitiba, 2006. Retrieved from: http://hdl.handle.net/1884/3884 on 5th September 2019.

BORTOLETTO JUNIOR, G. Estudo da qualidade da madeira de Pinus taeda L. provenientes de árvores adultas atingidas por incêndio florestal. 173 f. Tese. (Doutorado em Ciências Florestais) - Setor de Ciências Agrárias, Universidade Federal do Paraná, Curitiba,1999. Retrieved from: http://hdl.handle.net/1884/25310 on 5th September 2019.

BRAND, M. A.; KRAMBECK, L. B. P.; SIMÃ̃,R. L.; SANQUETTA, C. R.; SASSSO, J. G. Ensaio experimental de espécies do gênero Pinus na avaliação das propriedades mecânicas da madeira. In: III Encontro de Ciência e Tecnologia, 2004, Lages. Anais do III ECTec - Encontro de Ciências e Tecnologia. Lages, Universidade do Planalto Catarinense, 2004. Retrieved from:

https://www.academia.edu/8946794/BRAND_Ensaio_Experimental_de_Esp\%C3\%A9cies_do_G\%C3\%AAnero_Pinus_Aval ia\%C3\%A7\%C3\%A3o_das_Propriedades_Mec\%C3\%A2nicas_da_Madeira_1 on 1st September 2019.

CASTELO, P. A. R. Avaliação da qualidade da madeira de Pinus taeda em diferentes sítios de crescimento e espaçamentos, através do método não destrutivo de emissão de ondas de tensão. Tese (doutorado em Ciências Florestais) - Setor de Ciências Agrárias, Universidade Federal do Paraná - UFPR, Curitiba. 2007. Retrieved from: http://hdl.handle.net/1884/10090 on 5th September 2019.

FENGEL, D. WEGENER, G. Wood Chemistry, ultrastructure reactions. Berlin, 1989, 612 p.

Retrieved from: https://doi.org/10.1002/pol.1985.130231112 on 5th September 2019.

FIGUEROA, M. J. M.; MORAES P.D. Temperature reduction factor for compressive strength parallel to the grain. Fire Safety Journal. v. 83, p. 99-104, 2016. Retrieved from: https://doi.org/10.1016/j.firesaf.2016.05.005 on 5th September 2019.

FERRANTE, M. Seleção de Materiais, $3^{\text {a }}$ edição, São Carlos, EDUFSCA, 2013, 346p. Retrieved from: https://www.edufscar.com.br/selecao-de-materiais-3a-edicao on 14th august 2019.

IBÁ - Indústria Brasileira de Árvores. Relatório IBA 2017. São Paulo. 2017. Retrieved from: https://iba.org/images/shared/Biblioteca/IBA_RelatorioAnual2017.pdf on 14th august 2019.

KIM, Y, S.; FUNADA, R.; SINGH, A. P. Secondary Xylem Biology: Origins, Functions and Applications. South Korea: Gwangju, 2016. Retrieved from: https://www.sciencedirect.com/book/9780128021859/secondary-xylem-biology on 15th august 2019.

KLOCK, U. Manual Didático Química da Madeira. $3^{\mathrm{a}}$ edição revisada, Curitiba, 2005. Retrieved from: http://www.madeira.ufpr.br/disciplinasklock/quimicadamadeira/Quimica\%20da\%20Madeira\%202013.pdf on 22nd may 2018.

KWON, M.; BEDGAR, D. L.; PIASTUCH, W.; DAVIN, L. B.; LEWIS, N. G. Induced compression wood formation in Douglas fir (Pseudotsuga menziesii) in microgravity. Phytochemistry. v. 57, p. 847-857, 2001. Retrieved from: https://doi.org/10.1016/S0031-9422(01)00145-5 on 05th September 2019.

MATOS, J. L. M. Estudo sobre a produção de painéis estruturais de lâminas paralelas de P. taeda.117f. Tese (Doutorado em Ciências Florestais) - Setor de Ciências Agrárias, Universidade Federal do Paraná, Curitiba, 1997. Retrieved from: http://hdl.handle.net/1884/26741 on 5th September 2019.

MELCHIORETTO, D.; ELEOTÉRIO, J. R. Caracterização, classificação e comparação da madeira de Pinus patula, P. elliottii e $P$. taeda através de suas propriedades físicas e mecânicas. Congresso Regional de Iniciação Científica e Tecnológica, XVIII, 
Citation: Vinícius Rosa Schweitzer, et al., Influence of Silvicultural Techniques on the Occurrence of Compression Wood and Consequences on Wood Quality. Australian Journal of Basic and Applied Sciences, 13(10): 48-54. DOI: 10.22587/ajbas.2019.13.10.7

2003, Blumenau, SC. Anais... $\quad$ Blumenau, 2003. http://200.169.53.89/download/CD\%20congressos/2003/CRICTE on 02nd february 2012.

MENDES, L.M. Pinus spp. na produção de painéis de partículas orientadas (OSB). 163 f. Tese (Doutorado em Ciências Florestais) - Setor de Ciências Agrárias, Universidade Federal do Paraná, Curitiba, 2001. Retrieved from: http://hdl.handle.net/1884/26744 on 5th September 2019.

SANTINI, E. J.; HASELEIN, C. R.; GATTO, D. A. Análise comparativa das propriedades físicas e mecânicas da madeira de três coníferas de florestas plantadas. Ciência Florestal, v.10, n.1, p.85-93 85, 2000. Retrieved from https://periodicos.ufsm.br/cienciaflorestal/article/view/397/269 on 2nd may 2018.

SEVERO, E. T. D.; CALONEGO, F. W.; SANSÍGOLO, C. A. Composição química da madeira de Eucalyptus citriodora em função das direções estruturais. Silva Lusitana, v. 14, n.1, p. 113-126, 2006. Retrieved from: http://www.scielo.mec.pt/pdf/slu/v14n1/v14n1a09.pdf on 22nd May 2018.

TIMELL, T. E. Chemical properties of compression wood. Compression wood in gymnosperms, v. 1, p. 289-408, 1986. Retrieved from: https://www.sciencedirect.com/topics/agricultural-and-biological-sciences/compression-wood 22nd may 2018.

TRIANOSKI, R. Avaliação da Qualidade da Madeira de Espécies de Pinus Tropicais por meio de Métodos Convencionais e Não Destrutivos. 2012. Tese (Doutorado em Ciências Florestais) - UFPR, Curitiba. 2012. Retrieved from: http://hdl.handle.net/1884/28070 on 5th September 2019.

TRIANOSKI, R.; MATOS, J. L. M.; IWAKIRI, S.; PRATA, J. G. Variação Longitudinal da Densidade Básica da Madeira de Espécies de Pinus Tropicais. Floresta. v. 43, n. 3, p. 503-510, 2013. Retrieved from: http://dx.doi.org/10.5380/rf.v43i3.28252 on 5 th september 2019.

TRIANOSKI, R.; MATOS, J. L. M.; IWAKIRI, S.; PRATA, J. G. Avaliação das propriedades mecânicas da madeira de espécies de Pinus tropicais. Scientia Forestalis (IPEF), v. 42, p. 21-28, 2014. Retrieved from: https://www.ipef.br/publicacoes/scientia/leitura.asp?Article=02\&Number=101 on 5th september 2019.

TOMAZELLO, M. F.; Análise da madeira de compressão em Pinus oocarpa: estrutura anatômica e quantificação. IPEF. Boletim técnico, n. 37, p. 61-68, 1987. Retrieved from: https://www.ipef.br/publicacoes/scientia/nr37/cap07.pdf on 22 may 2018.

YAMASHITA S.; YOSHIDA, M.; YAMAMOTO, H.; Relationship between development of compression wood and gene expression. Plant Science. v. 179, p. $729-735, \quad 2009 . \quad$ Retrieved from: https://www.sciencedirect.com/science/article/pii/S0168945209000624?via\%3Dihub on 5th september 2019. 